\title{
Management of Irrigation Water for Cucumber Crop by Using Drip Irrigation Systems under Greenhouse
}

\author{
Esraa MI Masria $^{1 *}$, Abd-Gany M El-Gandy ${ }^{1}$, Kaled F El-Bagory ${ }^{1}$, \\ Essam A Wassif ${ }^{2}$ \\ 1- Agric Engineering Department, Faculty of Agriculture, Ain Shams University, P.O. Box 68, Hadayek \\ Shoubra 11241, Cairo, Egypt \\ 2- Irrigation and Drainage Department, Agric Eng Res Inst, Agric Res Centre, 12619, Giza, Egypt \\ * Corresponding author: esraamasria74@gmail.com
}

DOI:10.21608/ajs.2021.79143.1387

Received 4 June, 2021 ; Accepted 5 September, 2021

\section{Keywords:}

Surface drip irrigation, Sub-surface drip irrigation, Greenhouse, Water use efficiency

\begin{abstract}
This study aimed to examine the consequences of three regimes for irrigation on cucumber crops and their growth indication, production, and water productivity under greenhouse cultivation. Cucumber seedlings were planted in May 2018 under a greenhouse condition. Three regimes of drip irrigation were examined, first $100 \%, 80 \%$, and $50 \%$ of ETc namely T1, T2, and T3, respectively. Second regime was systems of drip irrigation (surface and sub-surface irrigation), finally the third is drippers discharge which used $(2 \mathrm{l} / \mathrm{h}$ and $4 \mathrm{l} / \mathrm{h}$ ). Results indicated clearly that the best production was under $80 \%$ ETc regime by $21 / \mathrm{h}$ dripper for surface and subsurface that was 10.1 and 11.2 ton/greenhouse respectively with IR $172 \mathrm{~m}^{3} / \mathrm{season}$ and the best regime by using $4 \mathrm{l} / \mathrm{h}$ was $50 \%$ ETc for surface and sub-surface respectively which was 11 and 11.5 ton/greenhouse with IR $216 \mathrm{~m}^{3} / \mathrm{season}$ which saved about half a quantity of irrigation water. On the other hand, the very best water productivity value (WP) was under $80 \%$ ETc was 58.7 and 65.4 $\mathrm{kg} / \mathrm{m}^{3}$ under surface (S) and sub-surface (SS) drip irrigation respectively by 2 $1 / \mathrm{h}$ dripper flow rate.
\end{abstract}

\section{Introduction}

Water-saving in the agricultural sector is a very important factor for Egypt's water scarcity to serve the growing population with the limited resources. Recently, cultivating vegetables under greenhouses in Egypt has been expanding rapidly. The number of greenhouses reached about twenty thousand, where about $12000(60 \%)$ are used for cucumber production (EL-Aidy et al 2007).

Under greenhouses cucumber crop is one of the most popular and best vegetables grown in the Arab Republic of Egypt. Irrigation scheduling has a significant effect on growing cucumber crops by irrigation water volume which adding during un- der different growth stages (Mao et al 2003). It gives more production under greenhouse cultivation than the open field (Maklad et al 2012).

Usually, drip irrigation systems used under greenhouse Cause of saving water with increasing fruit yield and improved WP due to consumption of less water (Berihun et al 2011), any degree of water deficits may produce deleterious effects on the growth and yield of the crop (Saifet et al 2003).

Water scheduling application is an effective way on drip irrigation system efficiency, by reducing irrigation amount, while the causes of water stress are the inadequate irrigation. (Deng et al 2006, Zaman et al 2001). 
This study aimed to search out technologies for water-saving by maximizing production by employing the drip irrigation regimes for irrigating cucumber crops under greenhouse conditions.

\section{Materials and Methods}

\subsection{Materials}

\subsubsection{Soil and water characteristics}

The soil of the experimental greenhouse is assessed as silty clay texture by mechanical analysis of homogeneous soil of the experiment at $40 \mathrm{~cm}$ depth which is suitable for cucumber growing roots details showed in Table 1. The irrigation well was $40 \mathrm{~m}$ depth with $10 \mathrm{~m}$ diameter and irrigation groundwater characteristics are detailed in Table 2.

\subsubsection{Climate data}

The climatic data were obtained from a meteorological station located next to the field of experiment and accustomed estimate the ETo data because the microclimate may be a major think about this study, these following data were recorded at Central Laboratory for Agriculture Climate (CLAC 2018) during growth season showed in Table 3.

\subsubsection{The greenhouse experiment}

A field study was at an experimental greenhouse of Agriculture Research Centre, located at Dokii, Egypt, (Latitude $30^{\circ} \mathrm{N}$ and longitude $30^{\circ} \mathrm{N}$. The water source was groundwater from a well situated within the experimental area, an arch there is not any heating and air ventilation inside the chosen greenhouse, manufactured from wooden frames covered with transparent plastic roof polyethylene (PE) $120 \mu \mathrm{m}$ thickness plastic film protected with meshes of $20 \times 10$ threads $/ \mathrm{cm}^{2}$. The greenhouse used for this experiment was classified as low technology greenhouse, each of $3.2 \mathrm{~m}$ high, $40 \mathrm{~m}$ long, and $16 \mathrm{~m}$ wide $640 \mathrm{~m}^{2}$ area showed in Fig 1.

\subsubsection{Drip irrigation system}

The components of the system are described below:

1- Control head: It was at the water supplement source, a centrifugal pump 4"/3", driven by an electric engine $15 \mathrm{HP}$. The pump discharge is
$35 \mathrm{~m}^{3} / \mathrm{h}$ and $30 \mathrm{~m}$ lift, at width $1900 \mathrm{rpm}$ screen filter 3" (120 mesh), backflow prevention device, pressure gauges, pressure regulator, control valves to control the desired pressure at different part of the system, flowmeter, and chemical injection.

2- Fertilizer unit for injecting fertilizers into the irrigation system.

3- Main line: $75 \mathrm{~mm}$ diameter PVC pipes, and submain line: PVC pipes of $50 \mathrm{~mm}$ diameter.

4- Laterals: PE tubes $16 \mathrm{~mm}$ in diameter at the spacing of $50 \mathrm{~cm}$ distance, built-in $16 \mathrm{~mm}$ PE surface and sub-surface drip line with $2 \mathrm{l} / \mathrm{h}$ and $4 \mathrm{l} / \mathrm{h}$ emitter discharge at 1 bar operating pressure. The spacing was $50 \mathrm{~cm}$. The irrigation network is described in Fig 2.

\subsubsection{Cucumber plant}

Seedling's cultivation for cucumber (Cucumis sativus L.) was transplanted in May 2018 and harvested on August 2018 end as a summer cycle, with distance $(0.5 \mathrm{~m})$ between each cucumber seed, the length of season was 14 weeks. Cucumber (Cucumis sativus L.), Joyance variety at 10 days with stalk length $7-10 \mathrm{~cm}$, were planted at a rate of 960 saplings per 640 square meters, Treatments had the identical recommended amount of fertilizers.

\subsection{Methods}

\subsubsection{Experimental design}

The greenhouse designed in a splits plot with three replications where irrigation regimes (T1:100\%, $\mathrm{T} 2: 80 \%$ and $\mathrm{T} 3: 50 \%$ ) of estimated evapotranspiration, the greenhouse divided into 6 plots of $2 \mathrm{~m} \times 40 \mathrm{~m}$ area with $0.5 \mathrm{~m}$ spacing between them this description showed in Fig 3. Each plot has two built-in SDI (surface drip irrigation) and SSDI (sub-surface drip irrigation) with two different emitters, $2 \mathrm{l} / \mathrm{h}$ and $4 \mathrm{l} / \mathrm{h}$ to exam every irrigation regime which the best as showed in Fig 4. Irrigation was scheduled based on a water balance, calculated by (El-Gindy 2007).

\subsubsection{Evapotranspiration}

ETc, estimated from the potential evapotranspiration (ETo), and using the crop coefficient (Kc) proposed this equation,

$$
E T c=E T o * K c
$$

ETc: crop evapotranspiration localized irrigation system, $\mathrm{mm} /$ day,

Eto: reference crop evapotranspiration, $\mathrm{mm} /$ day and Kc: crop coefficient. 


\section{Arab Univ J Agric Sci (2021) 29 (3) 835-844}

Table 1. Physical properties of homogeneous soil of the experiment analyzed before cultivation

\begin{tabular}{|c|c|c|c|c|c|c|}
\hline \multirow{2}{*}{ Depth } & \multicolumn{3}{|c|}{ Soil particle size distribution \% } & \multirow{2}{*}{ Texture } & \multirow{2}{*}{$\begin{array}{c}\text { F.C\% At } \\
33 \text { KPa }\end{array}$} & \multirow{2}{*}{$\begin{array}{l}\text { P.W.P At } \\
1500 K P a\end{array}$} \\
\hline & Sand & Clay & Silt & & & \\
\hline$(0-50) \mathrm{cm}$ & $\begin{array}{c}8.1 \\
\text { sand }\end{array}$ & $\begin{array}{l}48.8 \\
\text { clay }\end{array}$ & $\begin{array}{c}43.1 \\
\text { silt } \\
\end{array}$ & Silty clay & 36 & 17 \\
\hline
\end{tabular}

Where: F.C: field capacity $\%$ and P.W.P: permanent wilting point were determined as percentage in weight $\%$.

Table 2. Irrigation water's chemical analysis

\begin{tabular}{|c|c|c|c|c|c|c|c|c|c|}
\hline \multirow{2}{*}{$\mathbf{p H}$} & \multirow{2}{*}{$\begin{array}{c}\mathbf{E C} \\
\mathbf{p p m}\end{array}$} & \multicolumn{8}{|c|}{ Soluble anions and cations (meq/I) } \\
\cline { 3 - 11 } & $\mathbf{C a}^{++}$ & $\mathbf{M g}^{++}$ & $\mathbf{N a}^{++}$ & $\mathbf{K}^{+}$ & $\mathbf{C O}_{3}^{-}$ & $\mathbf{H C O}_{3}^{-}$ & $\mathbf{S O}_{4}^{-}$ & $\mathbf{C l}^{-}$ \\
\hline 7.30 & 500 & 1.2 & 0.1 & 3.31 & 0.41 & 0.00 & 0.5 & 1.4 & 3.12 \\
\hline
\end{tabular}

Table 3. Average rooting depth and crop coefficient for cucumber crop (FAO 2011)

\begin{tabular}{|c|c|c|c|}
\hline Growth stage & Days no. & Kc & Date \\
\hline Initial Stage & 8 & 0.45 & 2 May :10 May 2018 \\
\hline Development Stage & 40 & 0.70 & 11 May: 20 June 2018 \\
\hline Mid-Season & 30 & 0.90 & 21 June: 20 July 2018 \\
\hline Late-Season & 25 & 0.75 & 21 July: 15 August 2018 \\
\hline
\end{tabular}
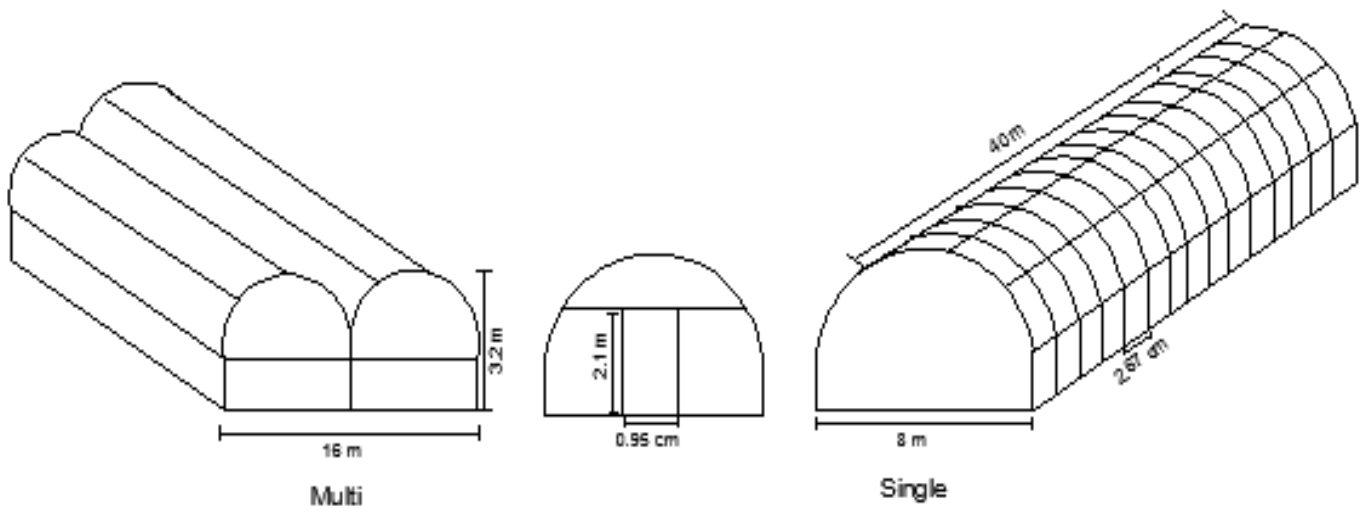

Fig 1. Greenhouse dimensions

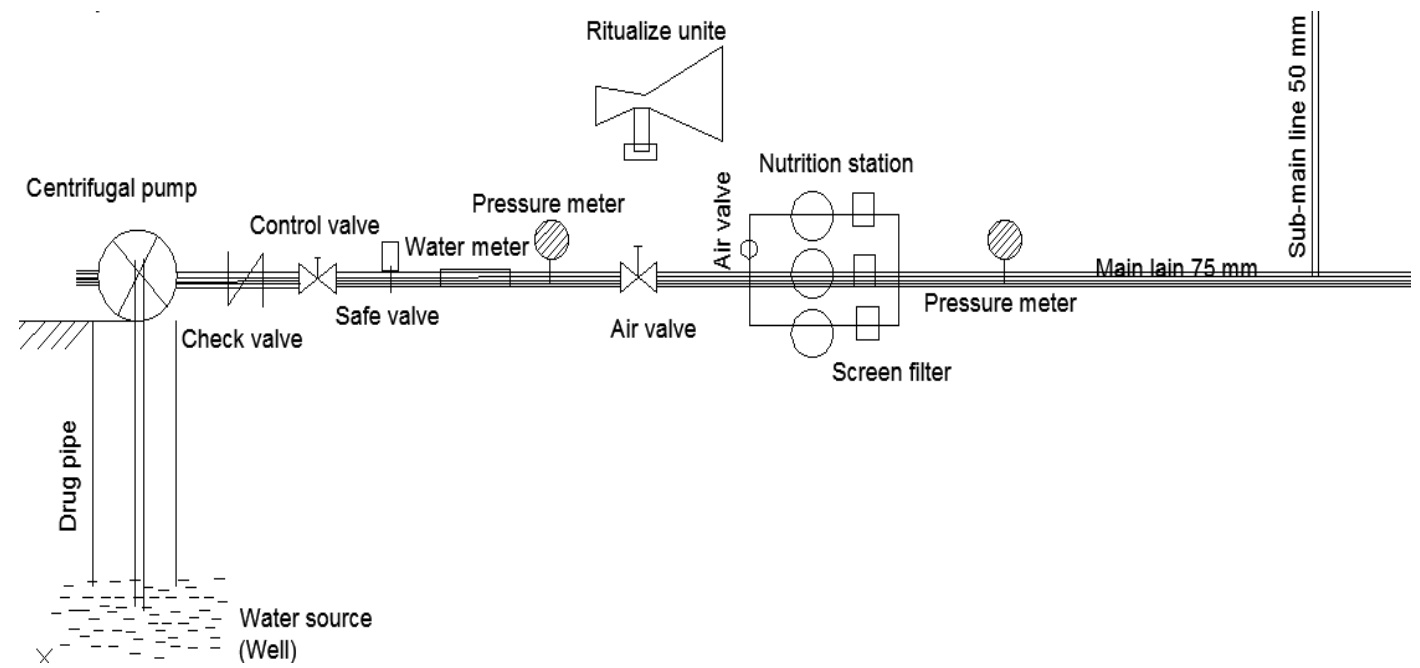

Fig 2. The layout of drip irrigation system component 
Arab Univ J Agric Sci (2021) 29 (3) 835-844

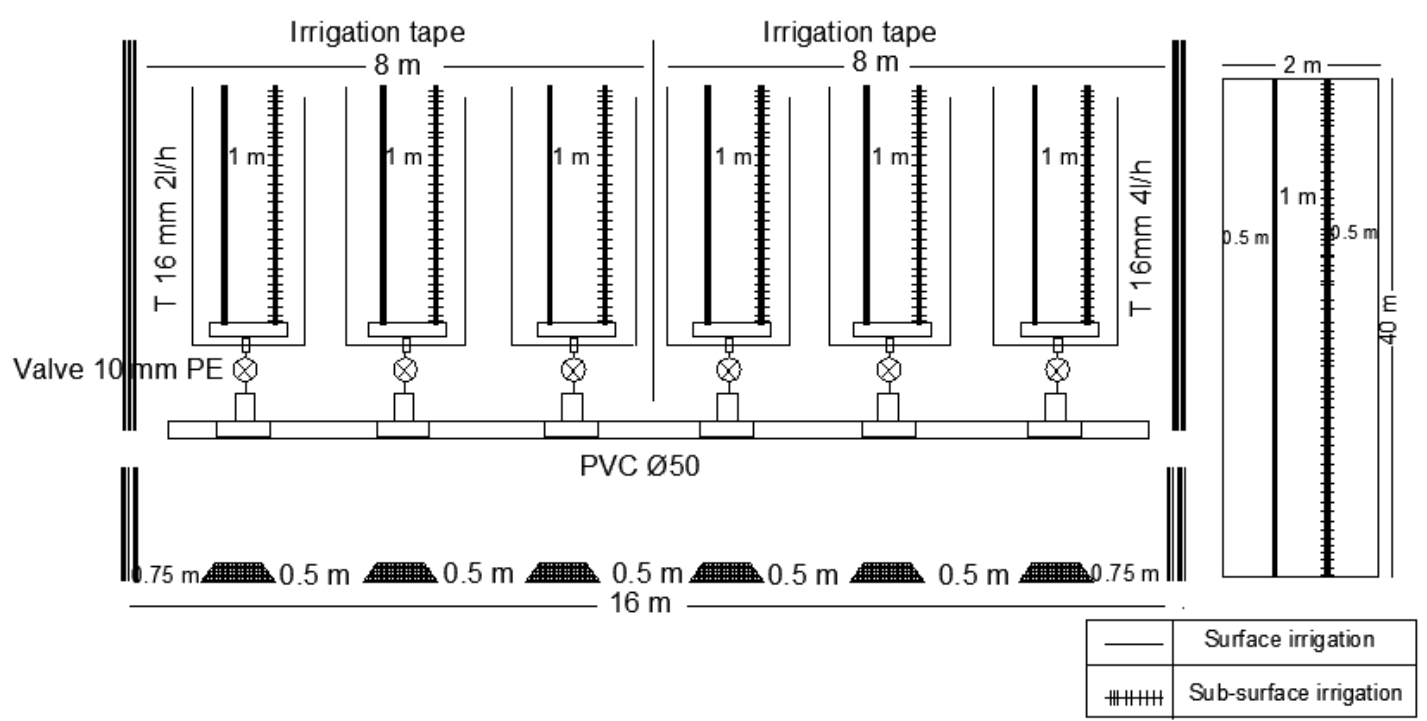

Fig 3. The layout of growing beds

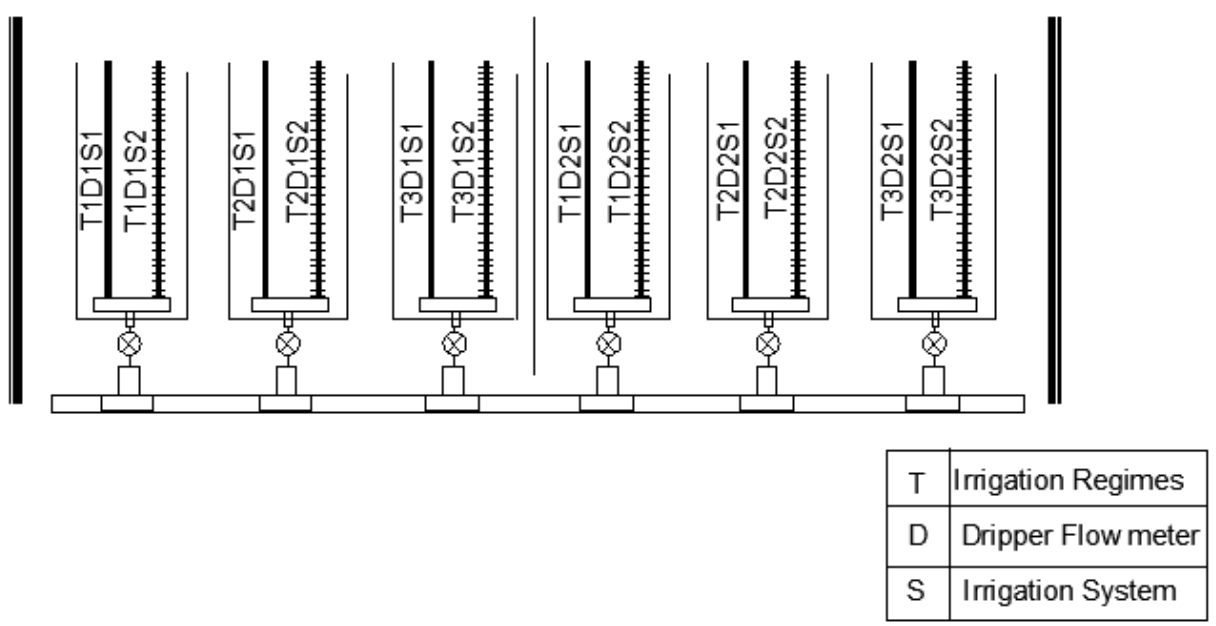

Fig 4. Irrigation treatments under greenhouse

\subsubsection{Irrigation requirement}

The water applied quantity for each treatment was calculated by the following equation (Howell 2003)

$I R=\frac{E \text { to. } K c \cdot A}{\text { ह. } A} * 0.7$

Where:

IR: irrigation requirement (1/greenhouse/day); ETo: reference crop evapotranspiration ( $\mathrm{mm} /$ day); Kc: crop coefficient; A: greenhouse area $\left(\mathrm{m}^{2}\right)$ and $\Sigma$ a: water application efficiency (Clark et al 2007).

By using the followed equation, total irrigation requirements $\mathrm{m}^{3} / \mathrm{season}$ under cultivating greenhouse could be estimated as showed in Table 4.

Calculating the amount of irrigation water which already added to cultivating greenhouse by following equation

$$
T=\frac{I R \cdot A}{Q} * 60
$$

T: time of irrigation (minute); IR: irrigation requirements for the plot $(\mathrm{mm})$; A: the area of the plot $\left(\mathrm{m}^{2}\right)$; Q: discharge of lateral in the greenhouse $(1 / \mathrm{h})$

Table 5 showed the quantity of water which already applied under different irrigation treatments under greenhouse cultivation.

\subsubsection{Water productivity (WP)}

By authors describing, is the ratio of crop yield or crop value, to a selected measure of water consumed, applied, or evaporated in the process of growing a crop. according to the following equation (Moldn et al 2010, Zwart et al 2004).

$W P=\frac{\text { crop yield (ton } / \mathrm{ha})}{\text { Applied water }(\mathrm{m} 3 / \mathrm{ha})}$ 
Table 4. Estimated irrigation requirement for greenhouse/season

\begin{tabular}{|c|c|c|c|c|c|c|c|c|}
\hline \multirow{2}{*}{$\begin{array}{l}\text { Growing } \\
\text { stage }\end{array}$} & \multirow{2}{*}{ Days } & \multirow{2}{*}{ Month } & \multirow{2}{*}{$\begin{array}{c}\text { ETo } \\
\text { mm/day }\end{array}$} & \multirow{2}{*}{ Kc } & \multirow{2}{*}{$\Sigma \mathbf{a}$} & \multicolumn{3}{|c|}{ IR $\mathrm{m}^{3} /$ growing stage } \\
\hline & & & & & & $100 \%$ & $\mathbf{8 0 \%}$ & $50 \%$ \\
\hline $\begin{array}{c}\text { Initial. Stage } \\
\text { (8 days) }\end{array}$ & 8 & May & 4.5 & 0.45 & \multirow{7}{*}{$95 \%$} & 9.4 & 7.2 & 4.6 \\
\hline \multirow{2}{*}{$\begin{array}{l}\text { Development. } \\
\text { (40 days) }\end{array}$} & 30 & June & 5 & \multirow[b]{2}{*}{0.70} & & \multirow[b]{2}{*}{80} & \multirow[b]{2}{*}{64} & \multirow[b]{2}{*}{40} \\
\hline & 10 & July & 5.1 & & & & & \\
\hline \multirow{2}{*}{$\begin{array}{c}\text { Mid-Season } \\
\text { (30 days) }\end{array}$} & 20 & July & 5.1 & \multirow[b]{2}{*}{0.90} & & \multirow[b]{2}{*}{76} & \multirow[b]{2}{*}{60} & \multirow[b]{2}{*}{38} \\
\hline & 10 & August & 4.6 & & & & & \\
\hline \multirow{2}{*}{$\begin{array}{c}\text { Late-Season } \\
(25 \text { days })\end{array}$} & 20 & August & 4.6 & \multirow[b]{2}{*}{0.75} & & \multirow[b]{2}{*}{48} & \multirow[b]{2}{*}{38} & \multirow[b]{2}{*}{22} \\
\hline & 5 & September & 3.6 & & & & & \\
\hline$\Sigma$ days & 103 & \multicolumn{4}{|c|}{ IR $\mathrm{m}^{3} /$ season } & 213.4 & 168 & 104.6 \\
\hline
\end{tabular}

Table 5. Applied water irrigation requirement for irrigation treatment under greenhouse

\begin{tabular}{|c|c|c|c|c|c|c|c|c|c|c|}
\hline \multirow{3}{*}{ Growing stage } & \multirow{3}{*}{ Month } & \multirow{3}{*}{$\begin{array}{l}\text { Irrigation } \\
\text { Time }\end{array}$} & \multirow{2}{*}{\multicolumn{2}{|c|}{$\begin{array}{c}\text { Line flow rate } \\
\left(\mathrm{m}^{3} / \mathbf{h}\right)\end{array}$}} & \multicolumn{6}{|c|}{ IR $\mathrm{m}^{3} /$ growing stage } \\
\hline & & & & & \multicolumn{2}{|c|}{$100 \%$} & \multicolumn{2}{|c|}{$80 \%$} & \multicolumn{2}{|c|}{$\mathbf{5 0 \%}$} \\
\hline & & & $21 / h$ & $41 / h$ & 2 & 4 & 2 & 4 & 2 & 4 \\
\hline Initial Stage & May & \multirow{6}{*}{40 mint. } & \multirow{6}{*}{0.16} & \multirow{6}{*}{0.32} & 17 & 34 & 13.6 & 26 & 8.4 & 17 \\
\hline \multirow{2}{*}{$\begin{array}{c}\text { Development } \\
\text { Stage }\end{array}$} & June & & & & 84 & 168 & 66 & 132 & 42 & 84 \\
\hline & July & & & & & 100 & 00 & 152 & 42 & \\
\hline Mid-Season & & & & & 64 & 128 & 50 & 102 & 32 & 64 \\
\hline Late-Season & August & & & & 52 & 104 & 40 & 80 & 26 & 52 \\
\hline \multicolumn{2}{|c|}{ Total Irrigation } & & & & 216 & 432 & 172 & 344 & 108 & 216 \\
\hline
\end{tabular}

\subsubsection{Soil and plant measurements}

There are numerous techniques for evaluating soil moisture. (Digital Mini Moisture) the meter was used for estimating soil moisture at $15-50$ $\mathrm{cm}$ profile soil depth at least that of the root penetration.

The data of growing plants were measured during the cucumber crop growth period to evaluate the whole yield, the height of the plant by using the meter to measure the height from the begging of the stalk to its end, and the fruit number harvested per plant.

\section{Results and Discussion}

\subsection{Irrigation requirements}

Results showed adding irrigation water requirements by using $2 \mathrm{l} / \mathrm{h}$ dripper discharge equal the estimating quantity of irrigation water requirement which supported by climatic factors approximately. Water applied under 50\% ETc treatment by $4 \mathrm{l} / \mathrm{h}$ dripper discharge equal the same quantity of water which applied under $100 \%$ ETc treatment by $21 / \mathrm{h}$ dripper discharge, as showed in Table 4. The results of irrigation regimes estimation agree with (Howell 2003).So, it is often used $2 \mathrm{l} / \mathrm{h}$ dripper rather than $4 \mathrm{l} / \mathrm{h}$ under $100 \%$ ETc irrigation or using $4 \mathrm{l} / \mathrm{h}$ dripper under $50 \%$ ETc irrigation level which saved $50 \%$ from total irrigation water.

\subsection{Soil moisture}

The average soil moisture content at (0-50) within the profile, the values as percentage in weight under different irrigation treatments for two sort of irrigation systems SDI and SSDI with $2 \mathrm{l} / \mathrm{h}$ and $41 / \mathrm{h}$ dripper flow. Water content for the soil was readings between two consecutive irrigations, the typical readings for every growing stage for the transplanted crop (initial stage, development, midseason, and harvest stage of cucumber).

Moisture within the profile initially showed the higher moisture altogether the treatments because of the quantity of applied water before transplanting to replenish the profile to field capacity and the treatments at different growth stages receive different 
quantities of water by different dripper 2 and $4 \mathrm{l} / \mathrm{h}$ which were $100 \%, 80 \%$, and $50 \%$ of ETc as irrigation water levels after transplanting.

Under $2 \mathrm{l} / \mathrm{h}$, after irrigation the soil moisture in the root zone area was lower than field capacity (F.C) but it didn't retch to (PWP) value under $50 \%$ irrigation regime. But under others regimes the soil moisture was equal field capacity (F.C) value then retched to (PWP) value after 48 hours from irrigation as showed in Fig 5.

Under $4 \mathrm{l} / \mathrm{h}$, it was equal the field capacity (F.C) then lowed to retch to the (PWP) under 50\% irrigation regime but under other regimes the soil moisture was higher than field capacity (F.C) then retched to be lower than P.W.P shown in Fig 6.

Soil moisture content under $100 \%$ ETc and $80 \%$ ETc had the same results by $21 / \mathrm{h}$ and $4 \mathrm{l} / \mathrm{h}$.

The results proved that using $2 \mathrm{l} / \mathrm{h}$ dripper discharge to irrigate the greenhouse under $80 \%$ ETc treatment had significant differences with other treatments on the soil moisture content under subsurface irrigated lines. Sub-surface drip irrigation (SSDI) had the highest value of soil moisture content under all irrigation regimes.

\subsection{Cucumber total production}

Yield was depending directly on the length of the harvest period. Yields range from about 1 to 3 Kg per plant per week during the highest harvest period. A stand harvest period of 14 weeks within the managed crop can yield a complete of 20 to 25 $\mathrm{Kg}$ per plant. Most cultivar trails show similar but somewhat lower yields from mini cucumber when put next to strength forward showed in Figs $\mathbf{7}$ and 8.

The $80 \%$ ETc irrigation level had the very best yield production was in comparison with other levels of irrigation under $2 \mathrm{l} / \mathrm{h}$ discharge of dripper, but under using $4 \mathrm{l} / \mathrm{h} 50 \%$ Etc was the best. The rate of reduction was $0.05 \%$ between $4 \mathrm{l} / \mathrm{h}$ and $2 \mathrm{l} / \mathrm{h}$ dripper discharge under sub-surface drip irrigation.

\subsection{Water productivity}

The differences in WP under irrigation treatments cause of the quantity of crop yield. Results proved that the yield was preserved under $80 \%$ ETc irrigation requirement. Although T1 had higher WP than that under $50 \%$ Etc. These results indicators in agreement with (Condon et al 2002, Hashem et al 2011).

There was clear interaction between irrigation type and irrigation water level treatments for WP. The WP values ranged from $34.2 \mathrm{Kg} \mathrm{m}^{-3}$ to $65.4 \mathrm{Kg} \mathrm{m}^{-3}$ depending on the interaction treatments, dripper flow rate and irrigation system. The very best WP value $65.4 \mathrm{Kg} \mathrm{m}^{-3}$ for SSDI under (80\% ETc) irrigation level by using $21 / \mathrm{h}$ dripper discharge. Generally, WP increase with SSDI and $2 \mathrm{l} / \mathrm{h}$ drippers compared to SDI system irrigation water applied as showed in Fig 9.

\subsection{Growth indicators}

\section{Plant height (m)}

The irrigation regime's effect on the height of plant, it compared statistically within treatments as Fig 10. showed that which achieved higher height under $100 \%$ ETc and $80 \%$ ETc regime compared with $50 \%$ ETc. Finally, $80 \%$ ETc obtained the highest height of plants under using $2 \mathrm{l} / \mathrm{h}$ dripper flow rate under sub-surface irrigation (SSDI). So, the idea about adding irrigation water quantity that was over or low had a relation with plant height cucumber crop.

These Results agree with (Hashem et al 2011, Ngouajio et al 2007) stated that the cucumber vegetative parameters were increased with the irrigation level of $80 \%$ ETc followed by $100 \%$ and $50 \%$ irrigation levels during Spring-Summer seasons, the increasing of vegetative parameters under $100 \%$ ETc irrigation level were attributed to the suitable irrigation quantity especially in the early stages of crop growth which enhanced a deeper and more extensive root system. 


\section{Arab Univ J Agric Sci (2021) 29 (3) 835-844}

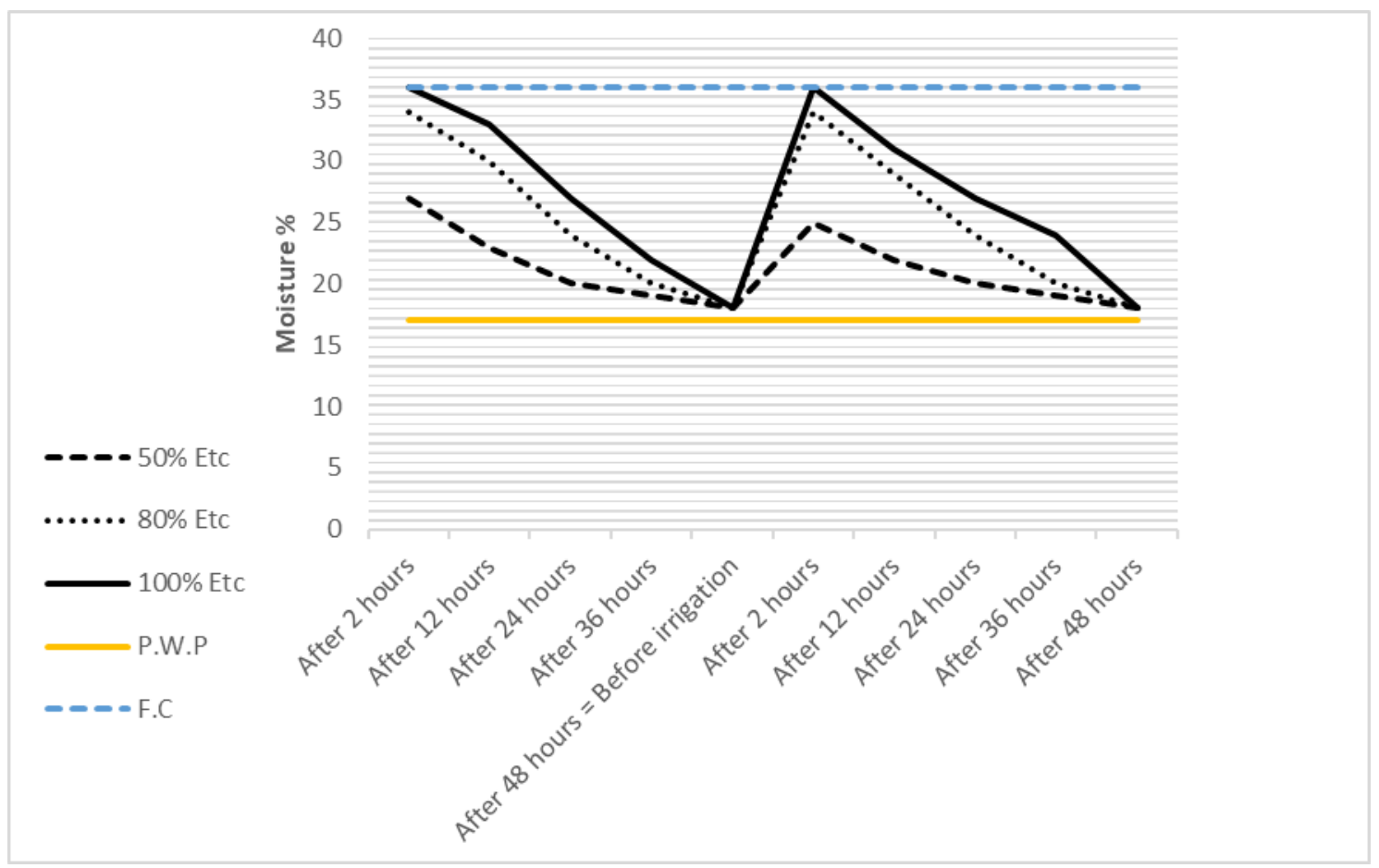

Fig 5. Average soil moisture content values as percentage in weight under three irrigation regimes for $21 / h$ flow rate dripper during the growth stage of cucumber crop

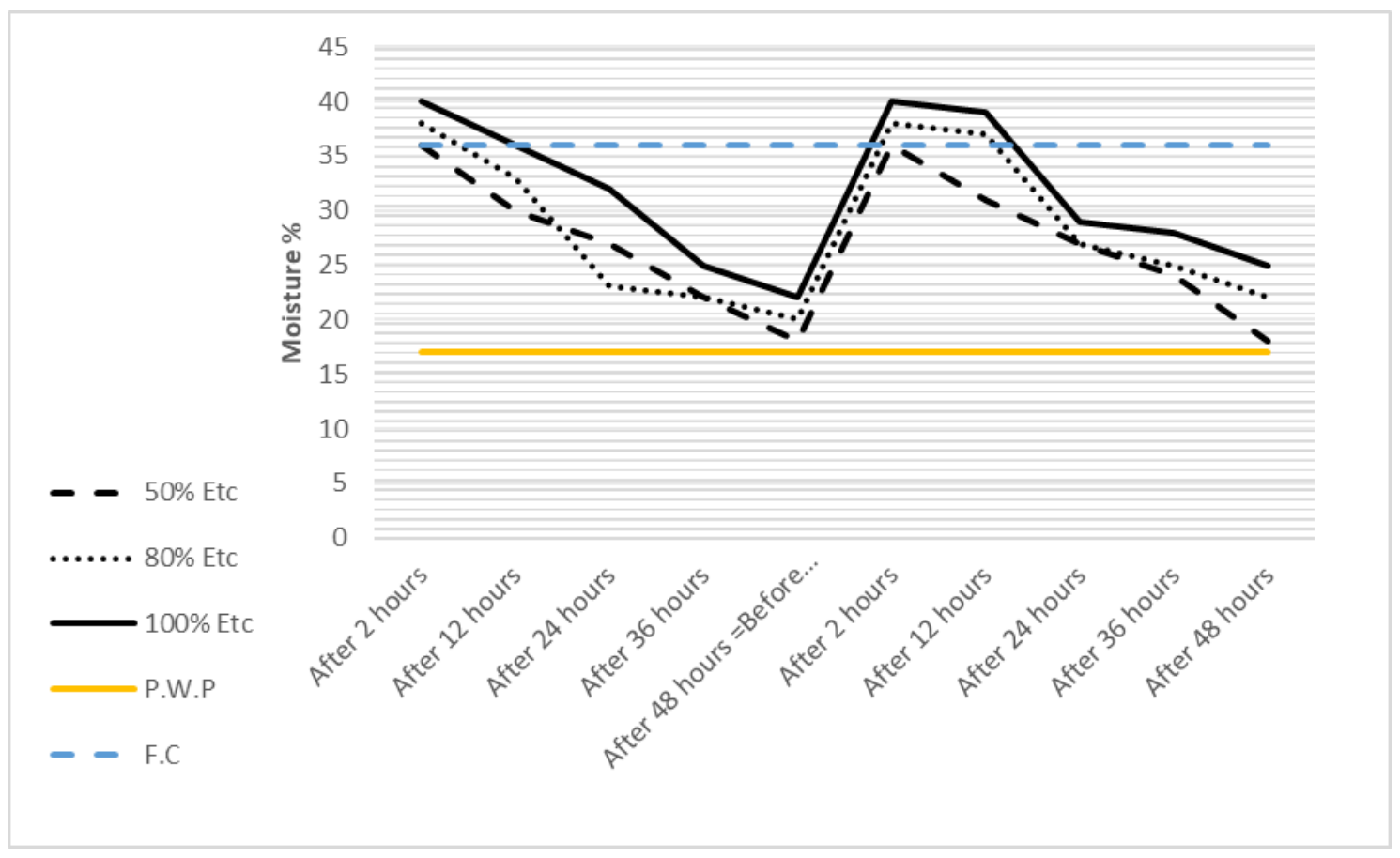

Fig 6. Average soil moisture content values as percentage in weight under three irrigation regimes for $41 / \mathrm{h}$ flow rate dripper during the growth stage of cucumber crop 
Arab Univ J Agric Sci (2021) 29 (3) 835-844

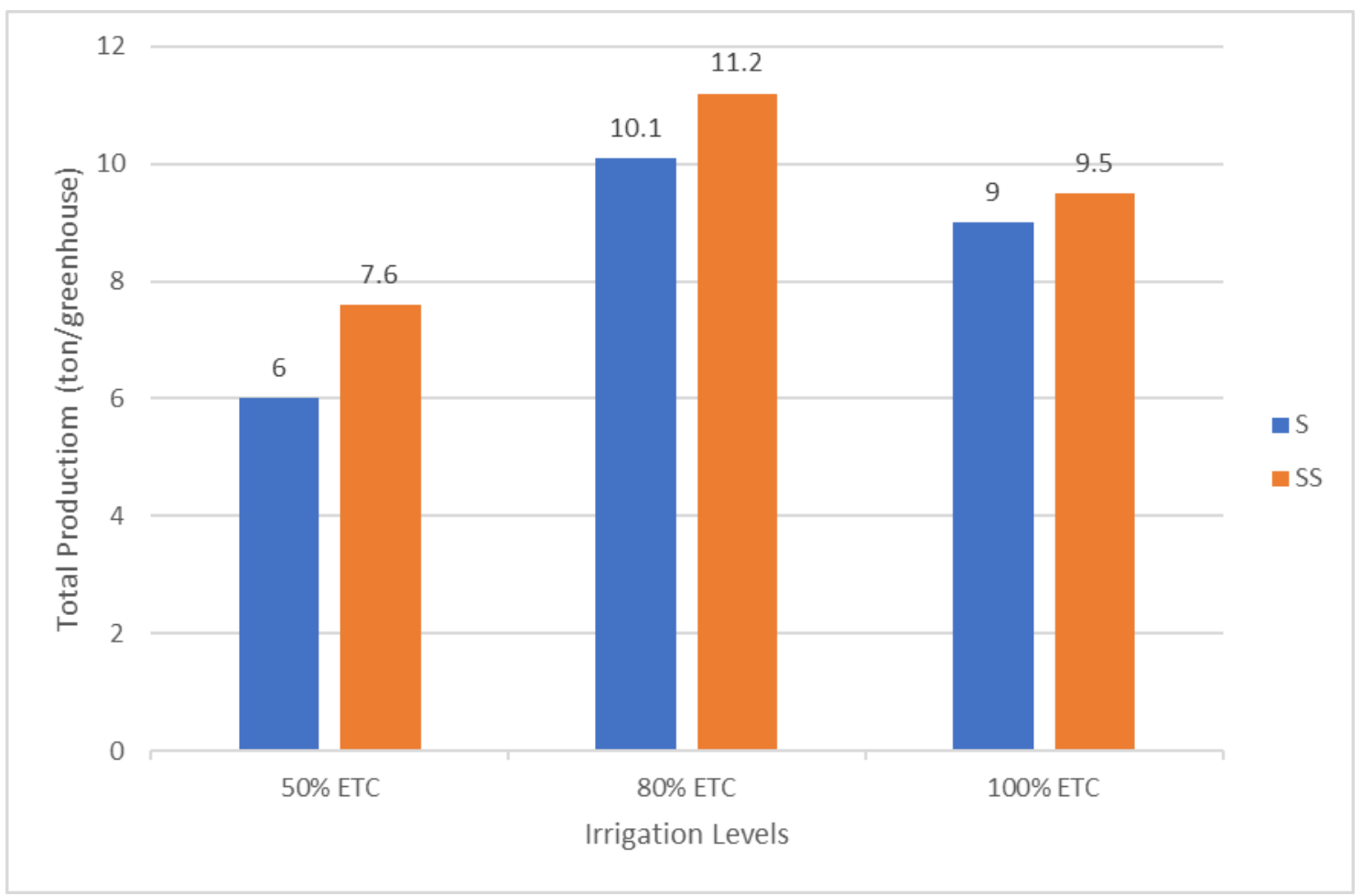

Fig 7. Total cucumber production under three irrigation levels for surface (S) and sub-surface (SS) drip irrigation system by using $2 \mathrm{l} / \mathrm{h}$ dripper

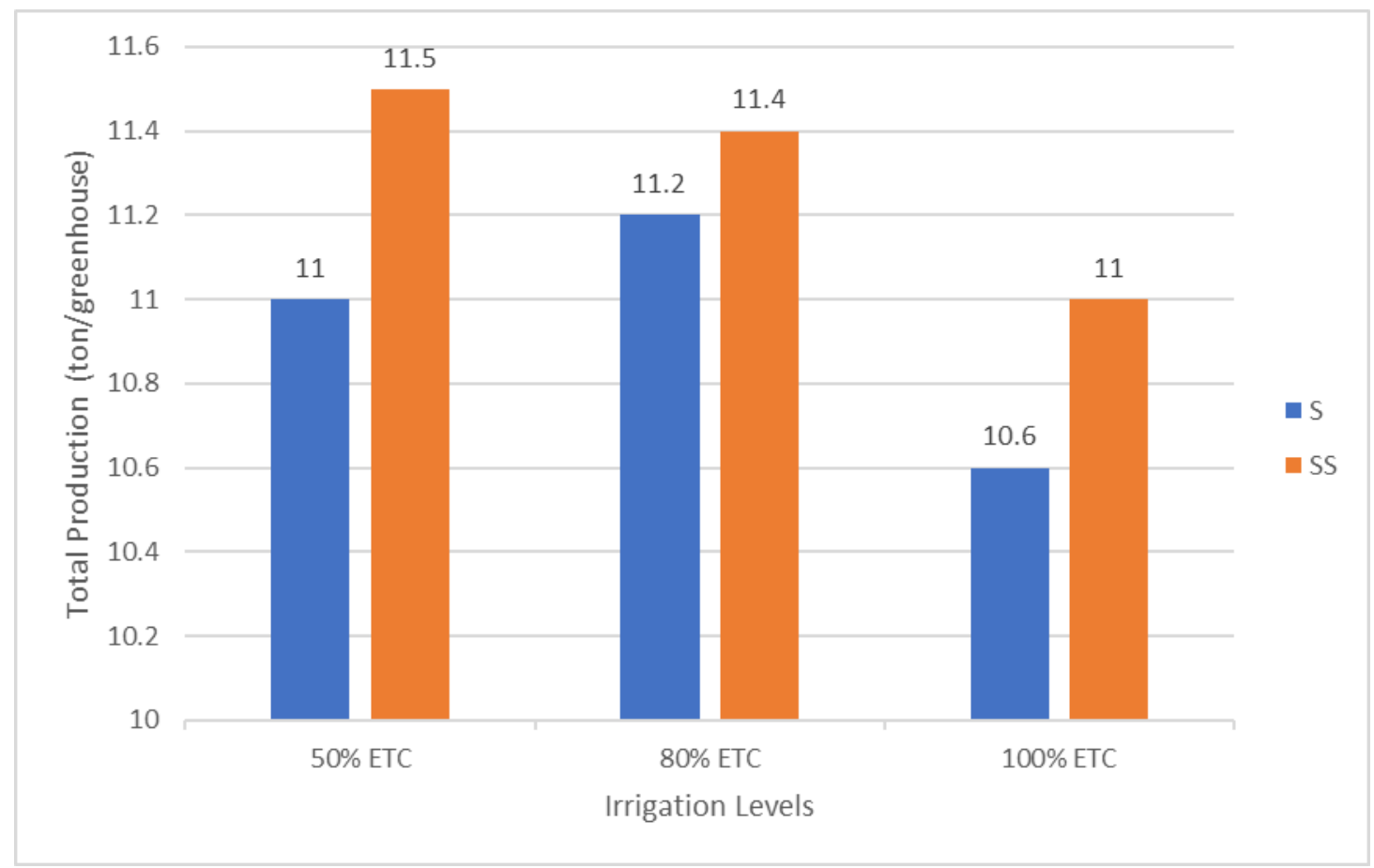

Fig 8. Total cucumber production under three irrigation levels for surface (S) and sub-surface (SS) drip irrigation system by using $4 \mathrm{l} / \mathrm{h}$ dripper 
Arab Univ J Agric Sci (2021) 29 (3) 835-844

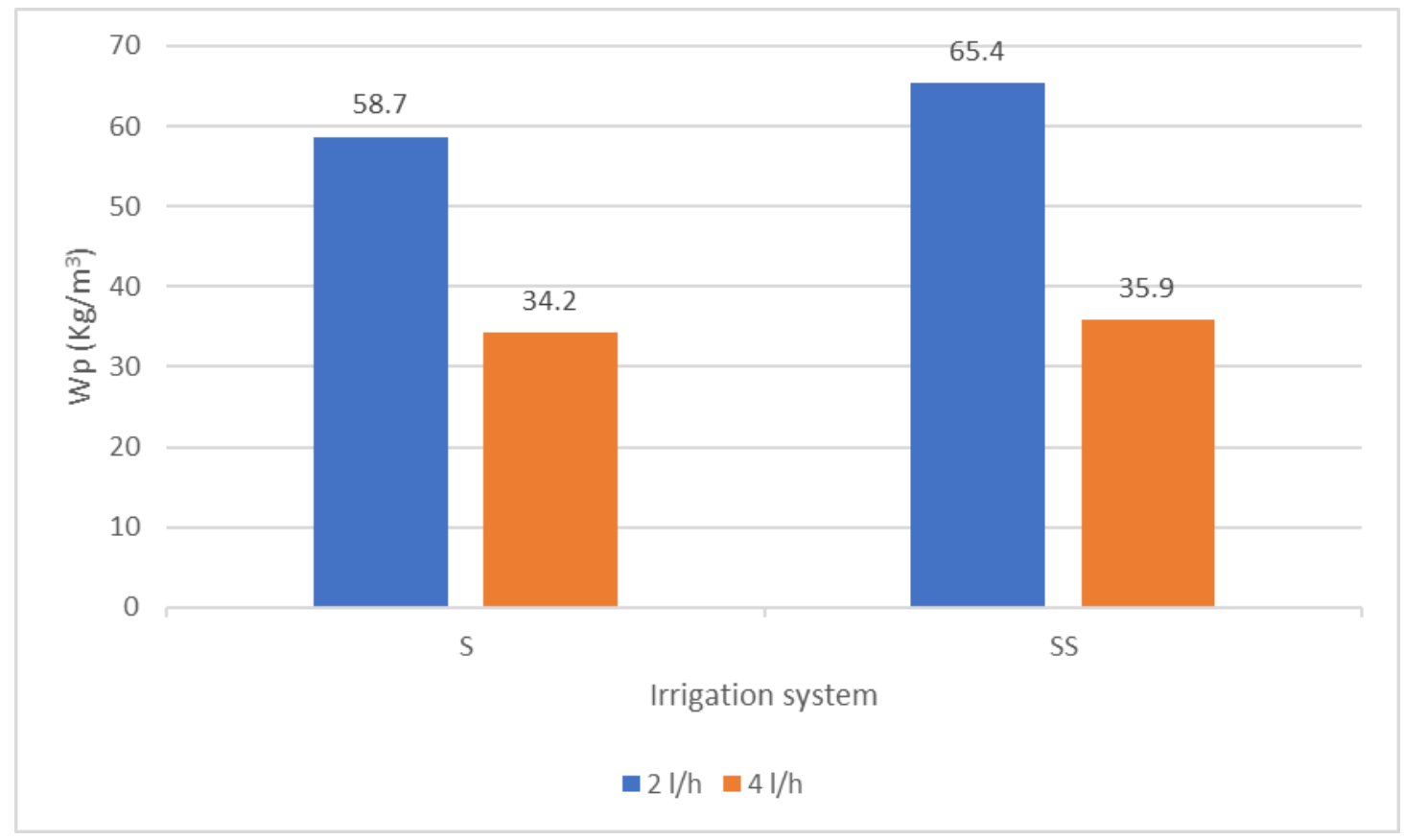

Fig 9. Water productivity (WP) under 80\% ETc irrigation level with using 2 1/h and 41/h flow meter under surface (S) and subsurface (SS) drip irrigation

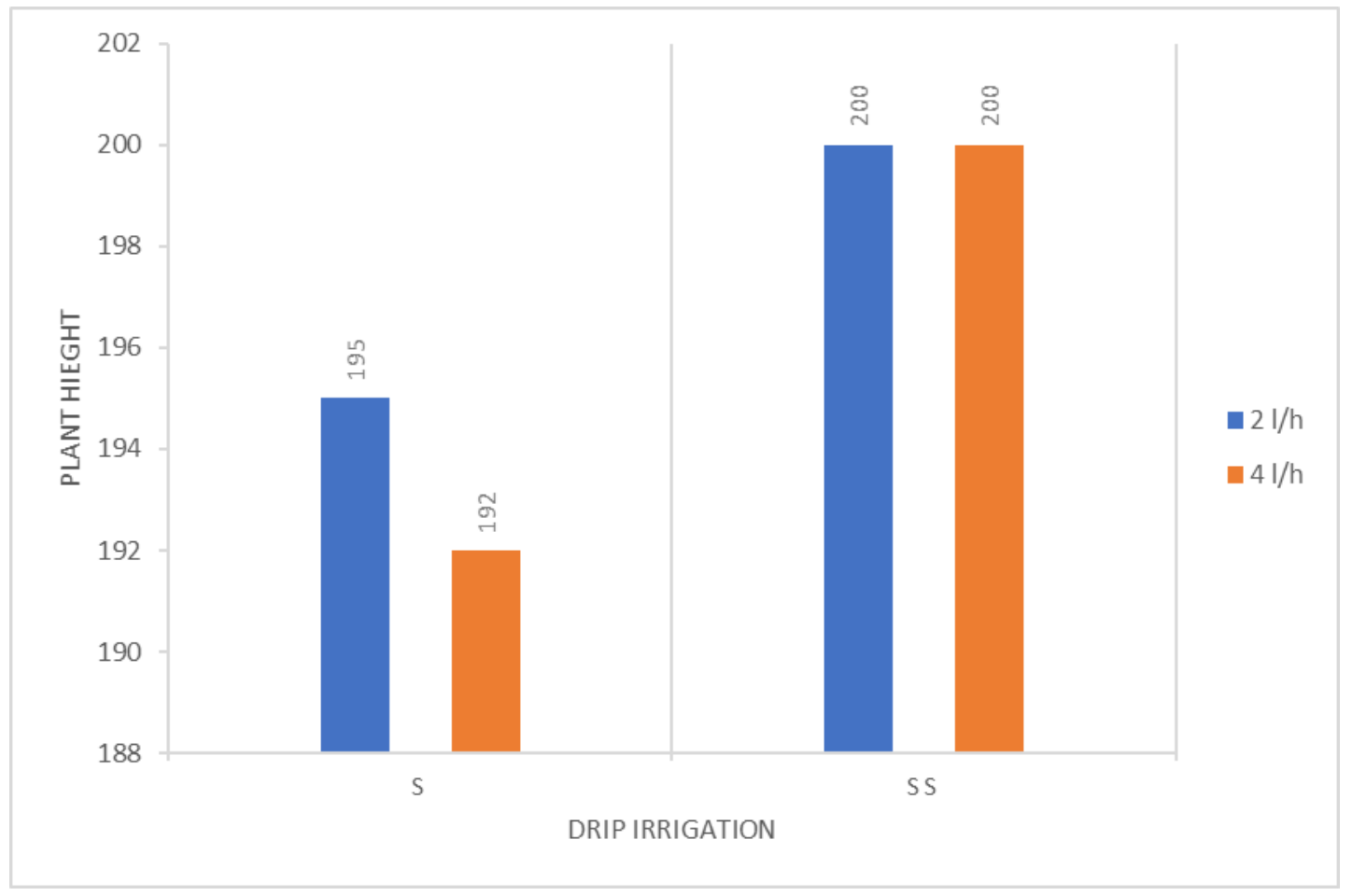

Table 10. The effect of drip discharge under surface (S), sub-surface (SS) irrigation on plant height (cm) for $80 \%$ ETc irrigation level 


\section{Conclusion}

It concluded that under conditions of the greenhouses, could be use $80 \%$ ETc irrigation regime which had the highest cucumber yield and water productivity. $21 / \mathrm{h}$ drip emitter discharge at $100 \%$ irrigation level gives the same quantity of water which gives with $41 / \mathrm{h}$ drip emitter discharge at $50 \%$ irrigation level. The research recommended using $2 \mathrm{l} / \mathrm{h}$ emitter discharge than $4 \mathrm{l} / \mathrm{h}$. On another side, the sub-surface drip system reduced the yield production of cucumber by $44 \%$. Study results demonstrated that the growth parameters (plant height, fruit number per plant) were increased by using $80 \%$ ETc throughout the cultivation season, which stimulated and encouraged the best growth for the plant.

\section{References}

Berihun B (2011) Effect of mulching and amount of water on the yield of tomato under drip irrigation. Journal of Horticulture and Forestry 3, 200206.

https://citeseerx.ist.psu.edu/viewdoc/download?do $\underline{\mathrm{i}=10.1 \cdot 1.1073 .4453 \& \mathrm{rep}=\mathrm{rep} 1 \& \text { type }=\mathrm{pdf}}$

CIAC (2018) Climatic Laboratory for Agricultural Centre, Giza, Egypt.

Clark GA, Haman DZ, Prochaska JF, Yitayew M (2007) General system design principles, In: Lamm FR, Nakayama FS (Eds). Micro-irrigation for Crop Production. E-Publishing Inc, New York, USA, pp 161-219.

Condon AG, Richards RA, Rebetzke GJ, Farquhar GD (2002) Improving intrinsic water use efficiency and crop yield. Journal of Crop Science 42, 122-131.

Deng XP, Shan L, Zhang H, Turner NC (2006) Improving agriculture water use efficiency in arid and semi-arid areas of China. Journal of Agricultural Water Management 80, 23-40.

DOI:10.1016/j.agwat.2005.07.021

EL-Aidy F, EL-Zawely A, Hassan N, EL-Sawy M (2007) Effect of plastic tunnel size on production of cucumber in delta of Egypt. Journal of Applied Ecology and Environmental Research 5, 11-24. http://www.aloki.hu/pdf/0502_011024.pdf

El-Gindy MA (2007) On-farm irrigation systems and technologies, 1 st ed, Police Press for Publishing and Distribution, Cairo, Egypt, pp 376-380.
FAO (2011) Martin S, Water Resource, Development and Management Service Rome, Italy pp 56.

Hashem FA, Medany MA, El-Moniem EM, Abdallah MMF (2011) Influence of Greenhouse Cover on Potential Evapo-Transpiration and Cucumber Water Requirements. Annal of Agricultural Sciences Journal 56, 49-55. DOI:10.1016/j.aoas.2011.05.001

Howell, TA (2003) Irrigation efficiency. In: Stewart BA, Howell TA, editors, Encyclopedia of water science. Marcel Dekker, New York, pp 467-472.

DOI:10.1081/E-EWS 120010252

Maklad AMH, Abolmaaty SM, Hassanein MH (2012) Impact of type of greenhouse cover sheets on certain major cucumber pests under protected cultivation. New York Science Journal 57, 19-24.

Mao X, Liu M, Wang X, Hou CZ, Shi J (2003) Effect of deficit irrigation on yield and water use of greenhouse grown cucumber in north china plain. Journal of Agricultural Water Management 61, 219-228. https://EconPapers.repec.org/RePEc:eee:agiwat:v: 61:y:2003:i:3:p:219-228

Molden D, Oweis T, Steduto P, Bindraban P, Hanjra MA (2010) Improving agricultural water productivity between optimism and caution. Agricultural Water Management 97, 528-553.

DOI:10.1016/j.agwat.2009.03.023

Ngouajio M, Wang G, Goldy R (2007) Withholding of drip irrigation between transplanting and flowering increases the yield of field-grown tomato under plastic mulch. Agricultural Water Management 87, 285-291. DOI:10.1016/j.agwat.2006.07.007

Saif U, Maqsood M, Farooq M, Hussain S, Habib A (2003) Effect of planting patterns and different irrigation levels on yield and yield component of maize (Zeamays, L.). International Journal of Agriculture and Biology 1, 64-66.

http://www.fspublishers.org/published_papers/70416_..pdf

Zaman WU, Arshad M, Saleem A (2001) Distribution of nitrate nitrogen in the soil profile under different irrigation methods. International Journal of Agriculture and Biology 2, 208-209.

Zwart SJ, Bastiaanssen WGM (2004) Review of measured crop water productivity values for irrigated wheat, rice, cotton and maize. Journal of Agricultural Water Management 69, 115-133. https://doi.org/10.1016/j.agwat.2004.04.007 